\title{
$\square$
}

\section{Three Funerals and a Wedding}

\author{
James B. Bullard
}

This article is a modified and updated version of a speech presented at the Regional Economic Summit, Evansville, Indiana, November 20, 2008.

Federal Reserve Bank of St. Louis Review, January/February 2009, 91(1), pp. 1-12.

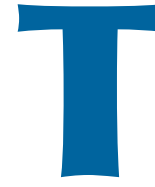

he U.S. economy continues to face substantial turmoil. Financial markets are under unusual stress. Wall Street has been racked by seismic change. Uncertainty over the future prospects for the U.S. economy has caused consumers and businesses to pull back on discretionary consumption and investment spending. Doubts concerning the true value of complex securities continue to weigh heavily on financial markets worldwide. The stilluncertain fate of housing markets has kept the value of the underlying mortgage assets obscured.

The Federal Reserve has been active and innovative in responding to the evolving turmoil during 2008. In addition to deploying interest rate cuts, the Fed has implemented a series of new and unconventional tools. This innovation has intensified in response to evolving market events. There may be many more twists and turns in the policy response going forward.

I will discuss the challenges my Federal Reserve colleagues and I face as we strive to implement a policy that is designed to deliver low and stable inflation along with maximum sustainable employment. I will describe three funerals and a wedding - that is, three ideas about the U.S. economy that may be going to their final resting place and one idea that, once left for dead, may be taking on a new life. I will keep you in suspense about what ideas I have in mind.

As always, any views expressed here are my own and do not necessarily reflect the official views of other Federal Open Market Committee members.

\section{THE FATE OF THE GREAT MODERATION}

A common description of current events is that some cherished theories about the macroeconomy have been shattered. One idea is that the fabled resiliency of the U.S. economy over the past several decades is being called into question. Policymakers and academics alike have described the period since the mid-1980s as the Great Moderation, meaning that the volatility of the economy has been markedly lower during recent decades than it was in the earlier part of the postwar era, and certainly much less than during the interwar period during the 1920s and 1930s. Now, that moderation and resiliency may be coming unraveled. If so, it would be a funeral for the Great Moderation.

Is it really true that the Great Moderation is coming to an end? My sense is that it is too early to

James B. Bullard is president of the Federal Reserve Bank of St. Louis. The author appreciates the assistance and comments provided by colleagues at the Federal Reserve Bank of St. Louis. Marcela M. Williams, special research assistant to the president, provided assistance.

(C) 2009, The Federal Reserve Bank of St. Louis. The views expressed in this article are those of the author(s) and do not necessarily reflect the views of the Federal Reserve System, the Board of Governors, or the regional Federal Reserve Banks. Articles may be reprinted, reproduced, published, distributed, displayed, and transmitted in their entirety if copyright notice, author name(s), and full citation are included. Abstracts, synopses, and other derivative works may be made only with prior written permission of the Federal Reserve Bank of St. Louis. 


\section{Figure 1}

\section{Real GDP Growth, 1950:Q1-2008:Q3}

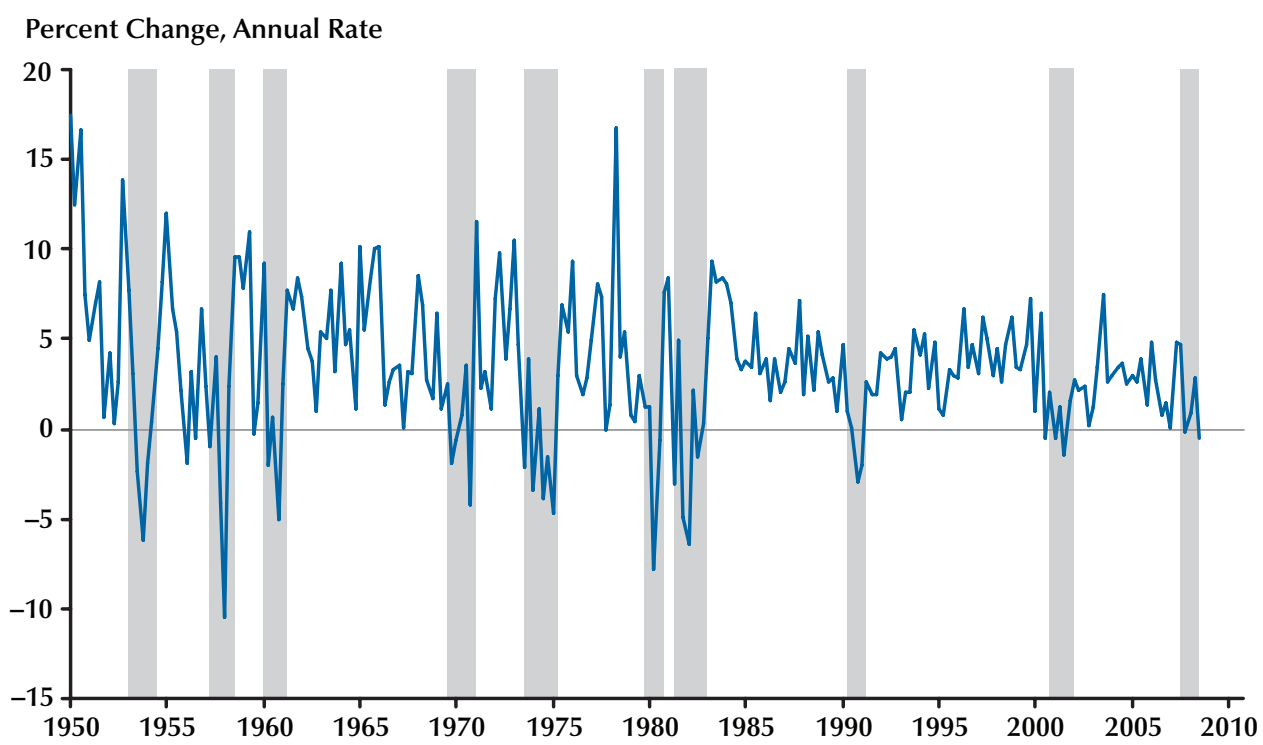

SOURCE: Bureau of Economic Analysis and National Bureau of Economic Research.

tell. Let's begin with a description of why policymakers and academics started talking about moderation and resiliency in the first place. The main idea is simple: Our primary measures of macroeconomic performance have been a lot less volatile than they were before 1984. In particular, quarterly gross domestic product (GDP) growth rates for the U.S. economy since 1945 show a clear change in behavior beginning in the middle 1980s. After 1984 , these growth rates are only about half as volatile as they were during the earlier period. ${ }^{1}$ So, for the past 25 years, growth rate volatility has dramatically moderated from what it was in the 1950s, 60s, and 70s (Figure 1).

Furthermore, this phenomenon is not limited to real GDP growth rates. Almost all macroeconomic data have been dramatically less volatile since the mid-1980s, according to academic research (Stock and Watson, 2003). So the Great Moderation is a clear feature of the U.S. macroeconomic data since the mid-1980s. And, as is

1 For a discussion and some theorizing about the Great Moderation, see Bullard and Singh (2007). often the case when the data show a clear pattern, theories abound about the causes of this phenomenon. But all the theories have a common themenamely, that some important macroeconomic event triggered a more stable, more resilient American economy over the past 25 years.

Understandably, many are yearning for a sense of stability today, and many are questioning what happened to the resiliency and moderation in the U.S. economy. Two areas stand out where volatility has been particularly high since the current financial turmoil began in earnest in August 2007. One is in certain interest rates and interest rate spreads, especially in markets that have experienced severe difficulties since the turmoil began. The closely watched LIBOR-Overnight Index Swap spread, for instance, peaked at more than 300 basis points before retreating in recent weeks. In July 2007, this spread was less than 10 basis points (Figure 2). Another volatile area is the equity markets: The Wilshire 5000 stock price index, one of the broadest measures of equity valuation, has been trading near its lows of 2002 


\section{Figure 2}

LIBOR, OIS, and Federal Funds Target Rate, January 3, 2007-December 10, 2008

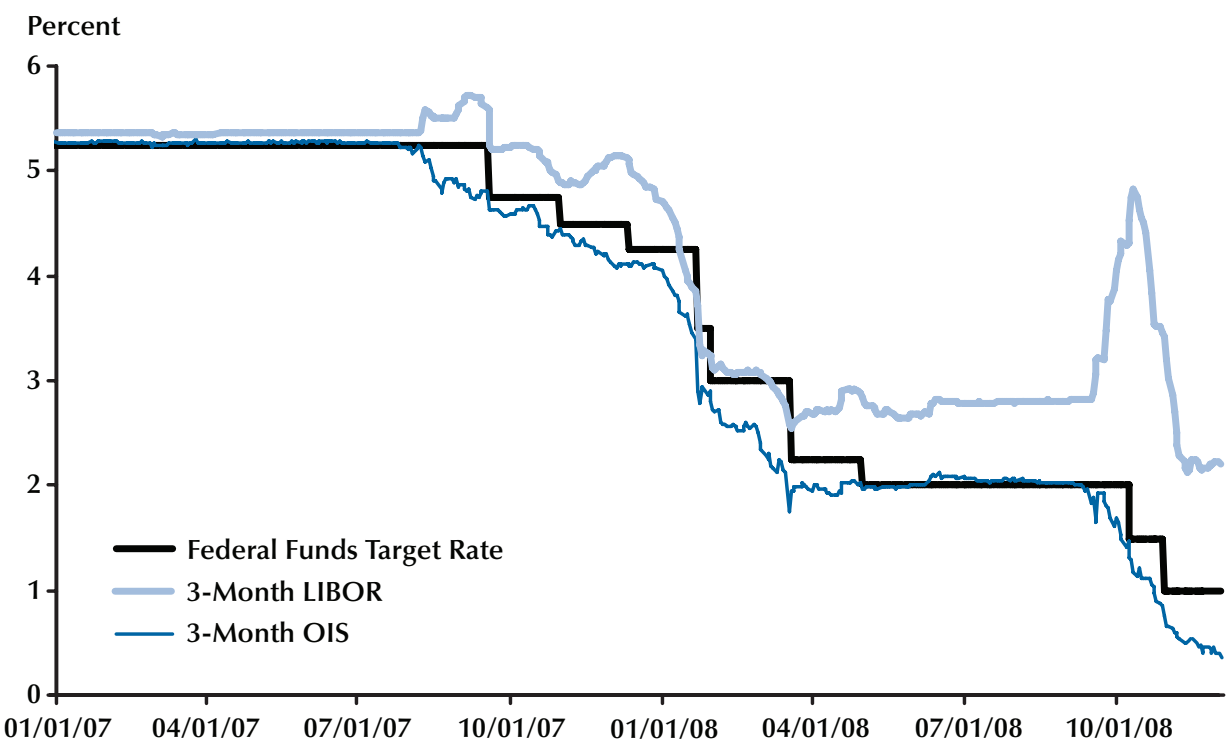

SOURCE: Federal Reserve Board, British Bankers' Association, Reuters.

\section{Figure 3}

Wilshire 5000 Price Index/Nominal GDP, 1980:Q1-2008:Q3

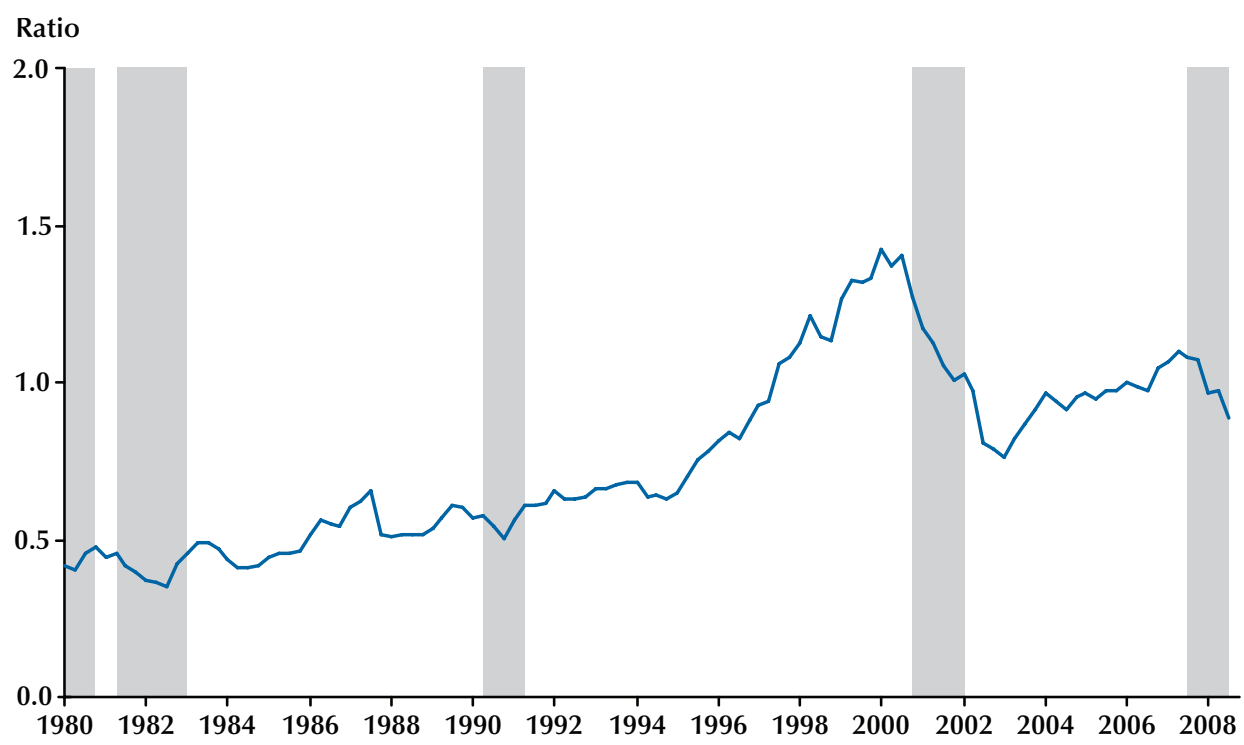

SOURCE: Wall Street Journal, Bureau of Economic Analysis, and National Bureau of Economic Research. 
Figure 4

\section{Chicago Board Options Exchange VIX, January 3, 2007-December 10, 2008}

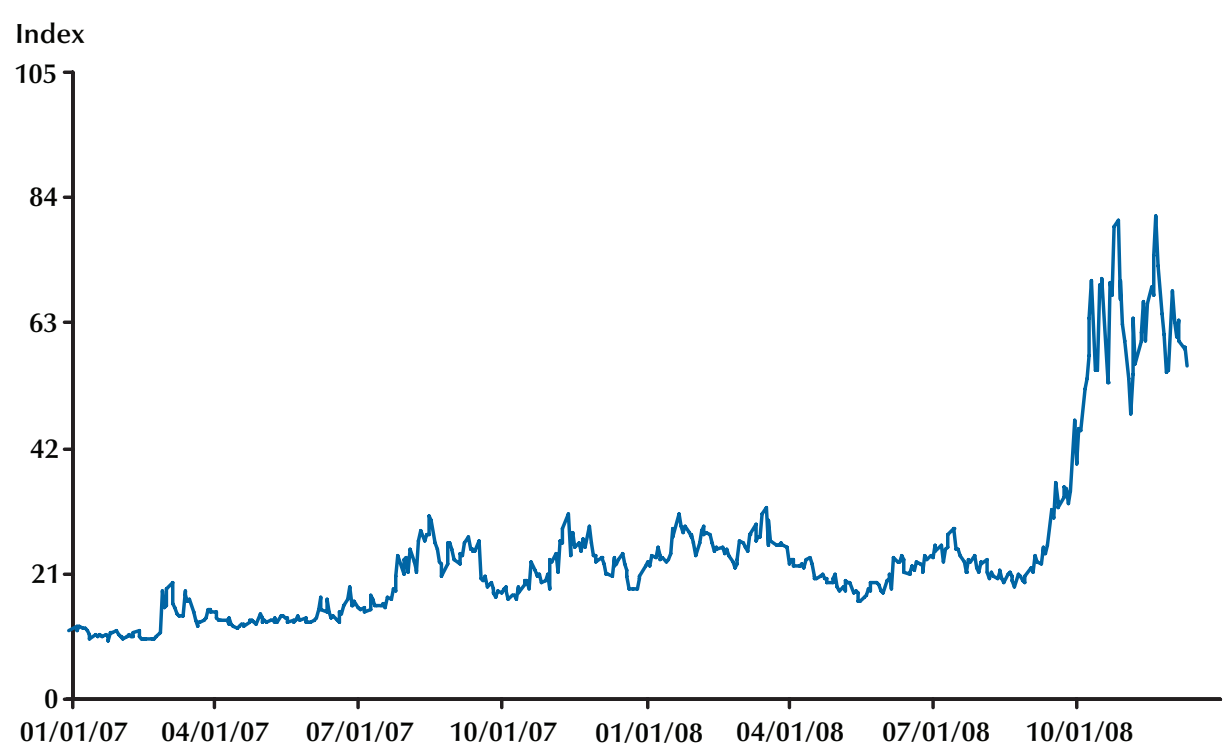

SOURCE: Wall Street Journal.

and 2003 in the past few weeks (Figure 3). The Chicago Board Options Exchange market volatility index (VIX) was often above 60 during October and November of this year; in July 2007 it was below 20. The dramatic rise in volatility based on numbers like these is clear (Figure 4).

Still, it is far too early to organize a funeral for the Great Moderation. Even though financial market volatility is exceptionally high and the U.S. economy is contracting during the second half of 2008, the demise of the Great Moderation would require much more evidence than currently exists. Real economic variables, in particular, would have to swing much more than they have to date, and the increased volatility would have to continue for a number of years before we could start to compare the current environment with the pre-1984 experience and pronounce the moderation dead. Real GDP has fallen by half a percent at an annual rate in the third quarter of this year. ${ }^{2}$ To be sure, fourth-quarter 2008 output is expected

2 The BEA preliminary estimate was released November 25, 2008. to fall sharply, followed by further but less-severe contraction in the first quarter of 2009. If that scenario materializes, the contour of the current recession will look much the same as that of the 1990-91 recession. As bad as that feels, it is not enough to undo 25 years of moderated behavior in the U.S. economy.

\section{CHANGES IN THE FINANCIAL MARKETPLACE}

It is no secret that the current financial market turmoil has brought about once-unimaginable changes on Wall Street. One telling sign of the magnitude of these changes is that the U.S. economy began 2008 with five large investment banks but will exit the year with zero. Without question, financial market turmoil since August 2007 is radically altering the nature of U.S. financial intermediation. I think it is fair to say that we are witnessing a funeral for the financial system we have known over the past two decades. 
A key culprit has been the illiquidity of mortgage-backed securities and related financial instruments. Many financial firms simply did not manage risk exposure on these securities well and as a result have struggled with losses and write-downs. The International Monetary Fund (2008) has estimated that more than $\$ 1.4$ trillion of losses will have to be absorbed by the financial sector before all is said and done in this episode and that only a portion of these losses have been accounted for to date. The opacity of the financial instruments involved has kept everyone guessing as to where these losses truly lie, which explains a lot about how events have unfolded during 2008. No firm has an incentive to declare that it may suffer debilitating losses, and so markets have to discover which firms are insolvent and which are likely to survive and build market share in the post-shakeout industry structure. The sharp downturn in the real economy during the fall of 2008 has intensified the pressure. In the meantime, firms have become wary of trading with one another, certain markets have ceased normal functioning, and market participants and policymakers alike have been confronted with a series of announcements from firms near bankruptcy. In a November 17 New York Times editorial, Treasury Secretary Paulson named the litany of firms experiencing "failure, or the equivalent of failures": Bear Stearns, IndyMac, Lehman Brothers, Washington Mutual, Wachovia, Fannie Mae, Freddie Mac, and the American International Group (Paulson, 2008).

The Federal Reserve has been forced to improvise in response to firms' announcements of this nature. The key concern has been that, if important financial market players are failing, the failure should occur in an orderly way with the lowest level of market disruption. In the banking sector, there are well-established procedures for resolving a failed institution in an orderly way. These procedures have served the nation well both during the current crisis and during the savings and loan episode during the late 1980s and early 1990s. It is very important to recognize that there are no such procedures in the non-bank financial sector today. This regulatory gap is likely to be a primary focal point for discussions of the future of finan- cial market regulation. In particular, any reform has to address the question of whether-and howto set up systems to resolve failing non-bank financial firms in an orderly way. The current system-bankruptcy court-is not working.

As the shakeout process has unfolded during 2008, markets have been continually bracing for further surprise announcements from financial firms. The policy response to this situation has been exceptionally aggressive (Table 1). Consider the largest S\&P 500 financial firms by assets as of the fourth quarter of 2007. The first 47 firms on the list accounted for 95 percent of the total assets held by the sector as of the fourth quarter of 2007. As of mid-summer 2008, just one of these financial firms had been the focus of a direct policy response of any kind. That firm was Bear Stearns, which, back in March, was purchased by JPMorgan Chase with help from the Fed. Almost all the others were operating as they had during recent years. The situation is dramatically different today. At the time of this writing, 22 of the 47 have received capital injections under the Treasury's Troubled Assets Relief Program (TARP) effort. Three of these are non-bank financial firms that changed their charters to become bank holding companies, including two of the largest firms on the list, Goldman Sachs and Morgan Stanley, and just recently American Express. Several other firms on the list merged with stronger partners, including Countrywide Financial and Merrill Lynch (both acquired by Bank of America), National City (acquired by PNC), Wachovia (acquired by Wells Fargo), and Sovereign Bancorp (approved acquisition by Banco Santander). The assets and debt obligations of Washington Mutual were purchased by JPMorgan Chase. Lehman Brothers went to bankruptcy court, but important portions of the company were acquired by Barclay's Capital. Fannie Mae and Freddie Mac were placed into conservatorship. American International Group has a restructured loan arrangement with the Treasury and the Federal Reserve. Citigroup has entered into an agreement to receive a package of guarantees, liquidity access, and capital from the government. These events have touched 33 of the 47 firms on the list. This means that much of the uncertainty surrounding the fate of U.S. finan- 
Table 1

Status of Large S\&P 500 Financial Firms

\begin{tabular}{|c|c|c|c|c|}
\hline Firm & $\begin{array}{c}\text { 1-year } \\
\text { percent change } \\
\text { in stock price } \\
11 / 30 / 07-11 / 28 / 08\end{array}$ & $\begin{array}{c}\text { Total assets } \\
\text { (\$ billions) } \\
(2007: \text { Q4) }\end{array}$ & $\begin{array}{c}\text { Percent of } \\
\text { total assets in } \\
\text { S\&P } 500 \text { financials }\end{array}$ & $\begin{array}{c}\text { Cumulative } \\
\text { percent }\end{array}$ \\
\hline Citigroup Inc. & $-75 \%$ & $\$ 2,187.63$ & $10.93 \%$ & $10.93 \%$ \\
\hline Bank of America Corp. & -65 & $1,715.75$ & 8.57 & 19.50 \\
\hline JPMorgan Chase \& Co. & -31 & $1,562.15$ & 7.80 & 27.31 \\
\hline Goldman Sachs Group & -65 & $1,119.80$ & 5.59 & 32.90 \\
\hline American International Group & -97 & $1,060.51$ & 5.30 & 38.20 \\
\hline
\end{tabular}

\begin{tabular}{|c|c|c|c|c|}
\hline Morgan Stanley & -72 & $1,045.41$ & 5.22 & 43.42 \\
\hline Merrill Lynch & -78 & $1,020.05$ & 5.10 & 48.52 \\
\hline Fannie Mae & -97 & 882.55 & 4.41 & 53.93 \\
\hline Federal Home Loan Mtg. & -97 & 794.37 & 3.97 & 56.90 \\
\hline Wachovia Corp. & -87 & 782.90 & 3.91 & 60.81 \\
\hline Lehman Bros. & -100 & 691.06 & 3.45 & 64.26 \\
\hline Wells Fargo & -11 & 575.44 & 2.88 & 67.14 \\
\hline MetLife Inc. & -56 & 558.56 & 2.79 & 69.93 \\
\hline Prudential Financial & -77 & 485.81 & 2.43 & 72.35 \\
\hline Hartford Financial Services Group & -91 & 360.36 & 1.80 & 74.16 \\
\hline Washington Mutual & N/A & 327.91 & 1.64 & 75.79 \\
\hline U.S. Bancorp & -18 & 237.62 & 1.19 & 76.98 \\
\hline Countrywide Financial Corp. & N/A & 211.73 & 1.06 & 78.04 \\
\hline Bank of New York Mellon Corp. & -37 & 197.66 & 0.99 & 79.03 \\
\hline Lincoln National & -78 & 191.44 & 0.96 & 79.98 \\
\hline SunTrust Banks & -55 & 179.57 & 0.90 & 80.88 \\
\hline Allstate Corp. & -50 & 156.41 & 0.78 & 81.66 \\
\hline SLM Corporation & -76 & 155.56 & 0.78 & 82.44 \\
\hline Principal Financial Group & -79 & 154.52 & 0.77 & 83.21 \\
\hline Capital One Financial & -35 & 150.59 & 0.75 & 83.96 \\
\hline National City Corp. & -90 & 150.37 & 0.75 & 84.71 \\
\hline American Express & -60 & 149.83 & 0.75 & 85.46 \\
\hline State Street Corp. & -47 & 142.54 & 0.71 & 86.17 \\
\hline Regions Financial Corp. & -61 & 141.04 & 0.70 & 86.88 \\
\hline PNC Financial Services & -28 & 138.92 & 0.69 & 87.57 \\
\hline BB\&T Corporation & -17 & 132.62 & 0.66 & 88.24 \\
\hline The Travelers Companies Inc. & -18 & 115.22 & 0.58 & 88.81 \\
\hline Genworth Financial Inc. & -94 & 114.32 & 0.57 & 89.38 \\
\hline
\end{tabular}

SOURCE: Securities and Exchange Commission, Standard \& Poor's, Federal Reserve Board, Wall Street Journal, and Government Accountability Office. 
Type of firm

$\mathrm{BHC}$

$\mathrm{BHC}$

$\mathrm{BHC}$

BHC

Insurance

BHC

Inv. bank

GSE

GSE

BHC

Inv. bank

Thrift

Insurance

Financial adv./insurance

Insurance

Thrift

BHC

Thrift

BHC

Insurance

$\mathrm{BHC}$

Insurance

Credit services

Financial adv./asset mgmt.

$\mathrm{BHC}$

$\mathrm{BHC}$

$\mathrm{BHC}$

$\mathrm{BHC}$

$\mathrm{BHC}$

$\mathrm{BHC}$

$\mathrm{BHC}$

Insurance

Insurance
Current status (as of 12/11/2008)

According to 11/24/08 plan: Treasury and FDIC backstop of $\$ 300$ billion in troubled assets; additional $\$ 20$ billion stake in the firm by the Treasury.

Acquired Countrywide Financial and Merrill Lynch.

Acquired Bear Stearns. Acquired Washington Mutual's secured debt obligations and deposits.

Has become a BHC.

Restructured plan, as of 11/10/08: $\$ 4$ billion equity stake by government, $\$ 30$ billion in funds on securities underlying the firm's CDS, $\$ 22.5$ billion to buy residential mortgage securities. It will reduce the previous credit line to $\$ 60$ billion.

Has become a BHC.

10

Acquired by Bank of America.

Placed into conservatorship.

Placed into conservatorship.

Bought by Wells Fargo.

Filed for bankruptcy; Barclay's has acquired important pieces. Bought Wachovia.

Capital from government investment plan

(\$ billions) as of $12 / 11 / 08$

Assets and debt obligations bought by JPMorgan Chase.

$-$

$-$

Merged into Bank of America.

$-$

3

$-$

3.5

$-$

$-$

$-$

$-$

3.555

$-$

2

3.5

$-$

3.134

$-$ 
Table 1, cont'd

Status of Large S\&P 500 Financial Firms

\begin{tabular}{|c|c|c|c|c|}
\hline Firm & $\begin{array}{c}\text { 1-year } \\
\text { percent change } \\
\text { in stock price } \\
\text { 11/30/07-11/28/08 }\end{array}$ & $\begin{array}{c}\text { Total assets } \\
\text { (\$ billions) } \\
(2007: \text { Q4) }\end{array}$ & $\begin{array}{c}\text { Percent of } \\
\text { total assets in } \\
\text { S\&P } 500 \text { financials }\end{array}$ & $\begin{array}{c}\text { Cumulative } \\
\text { percent }\end{array}$ \\
\hline Fifth Third Bancorp & $-68 \%$ & $\$ 110.96$ & $0.55 \%$ & $89.94 \%$ \\
\hline Ameriprise Financial Inc. & -69 & 109.23 & 0.55 & 90.48 \\
\hline KeyCorp & -64 & 99.98 & 0.50 & 90.98 \\
\hline Bear Stearns Cos. & $\mathrm{N} / \mathrm{A}$ & 96.08 & 0.48 & 91.46 \\
\hline CIT Group & -87 & 90.25 & 0.45 & 91.91 \\
\hline Sovereign Bancorp & -79 & 84.75 & 0.42 & 92.34 \\
\hline Loews Corp. & -43 & 76.08 & 0.38 & 92.72 \\
\hline ACE Limited & -13 & 72.09 & 0.36 & 93.08 \\
\hline Northern Trust Corp. & -43 & 67.61 & 0.34 & 93.41 \\
\hline AFLAC Inc. & -26 & 65.81 & 0.33 & 93.74 \\
\hline M\&T Bank Corp. & -29 & 64.88 & 0.32 & 94.07 \\
\hline E*Trade Financial Corp. & -71 & 64.19 & 0.32 & 94.39 \\
\hline Comerica Inc. & -51 & 62.33 & 0.31 & 94.70 \\
\hline Marshall \& Ilsley Corp. & -51 & 58.30 & 0.29 & 94.99 \\
\hline
\end{tabular}

SOURCE: Securities and Exchange Commission, Standard \& Poor's, Federal Reserve Board, Wall Street Journal, and Government Accountability Office.

cial companies has been addressed in one manner or another during the past several months. Turmoil is still significant, to be sure, but the policy response has been very aggressive, and many of the largest uncertainties have been addressed.

\section{FUNERAL FOR A FRIEND}

The financial market turmoil began during the summer of 2007. The initial analysis-widely accepted among policymakers and forecasterssuggested that problems in the subprime sector of the mortgage markets were unlikely to be large enough to have a substantial impact on the U.S. economy outside the financial sector. Markets seemed to confirm this judgment during the fall of 2007, as equity indexes peaked. By late 2007, however, it became apparent that problems were going to be more difficult and long-lasting than the original analysis suggested. Real GDP growth in the fourth quarter of 2007 was slightly negative based on the revised data available today. Employ - ment growth turned negative in January 2008.

The Fed responded to the weakening economy by easing aggressively, lowering the target federal funds rate by 225 basis points during the first few months of 2008 all the way down to 2 percent. During the summer, the Federal Open Market Committee (FOMC) went on hold, but intensified turmoil during the fall combined with weakerthan-expected data on the real economy triggered further easing moves during October. This has left the FOMC with a federal funds target at a low level, with further easing possible as weak data roll in over the next several months (Figure 5A).

Whether the FOMC decides to stay on hold at this point or eases further and then stays on hold at some lower level, even zero, may not be the most critical question. The fact is, monetary policy defined as movements in short-term nominal interest rates is coming to an end, at least for now. It's a funeral for a friend.

The end of nominal interest rate targeting in the United States for the near term means that 


\begin{tabular}{|c|c|c|}
\hline Type of firm & Current status (as of 12/11/2008) & $\begin{array}{c}\text { Capital from } \\
\text { government } \\
\text { investment plan } \\
(\$ \text { billions) } \\
\text { as of 12/11/08 } \\
\end{array}$ \\
\hline $\mathrm{BHC}$ & - & 3.45 \\
\hline Financial adv. & - & - \\
\hline $\mathrm{BHC}$ & - & 2.5 \\
\hline Inv. bank & Fed arranged merger with JP Morgan Chase. & - \\
\hline Credit services & - & - \\
\hline Thrift & Approved takeover by Banco Santander 10/13/08 & - \\
\hline Insurance/hotels & - & - \\
\hline Insurance & - & - \\
\hline $\mathrm{BHC}$ & - & 1.576 \\
\hline Insurance & - & - \\
\hline $\mathrm{BHC}$ & - & 0.6 \\
\hline Inv. brokerage & - & 0.8 \\
\hline $\mathrm{BHC}$ & - & 2.25 \\
\hline $\mathrm{BHC}$ & - & 1.715 \\
\hline
\end{tabular}

much more attention will have to be paid to alternative ideas about controlling inflation and inflation expectations going forward. An important characteristic of the current environment is that medium-term inflation expectations seem to be spreading out dramatically, with some analysis warning of high inflation, others warning of deflation, and still others expecting inflation to remain near the levels recently experienced.

One focus of analysis over the coming quarters will be the experience in Japan. Japan was buffeted by large declines in equity and real estate markets in the early 1990s. In response, the Bank of Japan lowered nominal interest rates to near zero by the middle of that decade, and it has not been above 1 percent since. An important part of the outcome in Japan has been a rate of deflation that has averaged about 1 percent since the mid-1990s (Figure 5B). Deflation, should it occur in the United States, might be particularly challenging because some of our current core problems are in housing markets, where contracts are written in nominal terms. An unexpected deflation would make those contracts more expensive for borrowers.

One idea from the Japanese experience is that with nominal interest rates at very low levels, more attention may have to be paid to quantitative measures of monetary policy. By announcing and maintaining targets for key monetary quantities, the Fed may be able to keep inflation and inflation expectations near target and ward off either a drift toward deflation or excessively high inflation. This will be an important issue for the Fed in coming months and represents a challenge in the communication of monetary policy going forward.

\section{A REBIRTH}

So far, I have discussed three funerals, ideas whose times may have passed. I now want to turn to a macroeconomic idea that is being rehabilitated as we speak. That idea is fiscal policy-in particular, the spending side of fiscal policy and the idea of more direct intervention in the affairs of private sector firms. 
Figure 5

A. Federal Funds Rate and CPI Inflation Rate, January 1986-November 2008

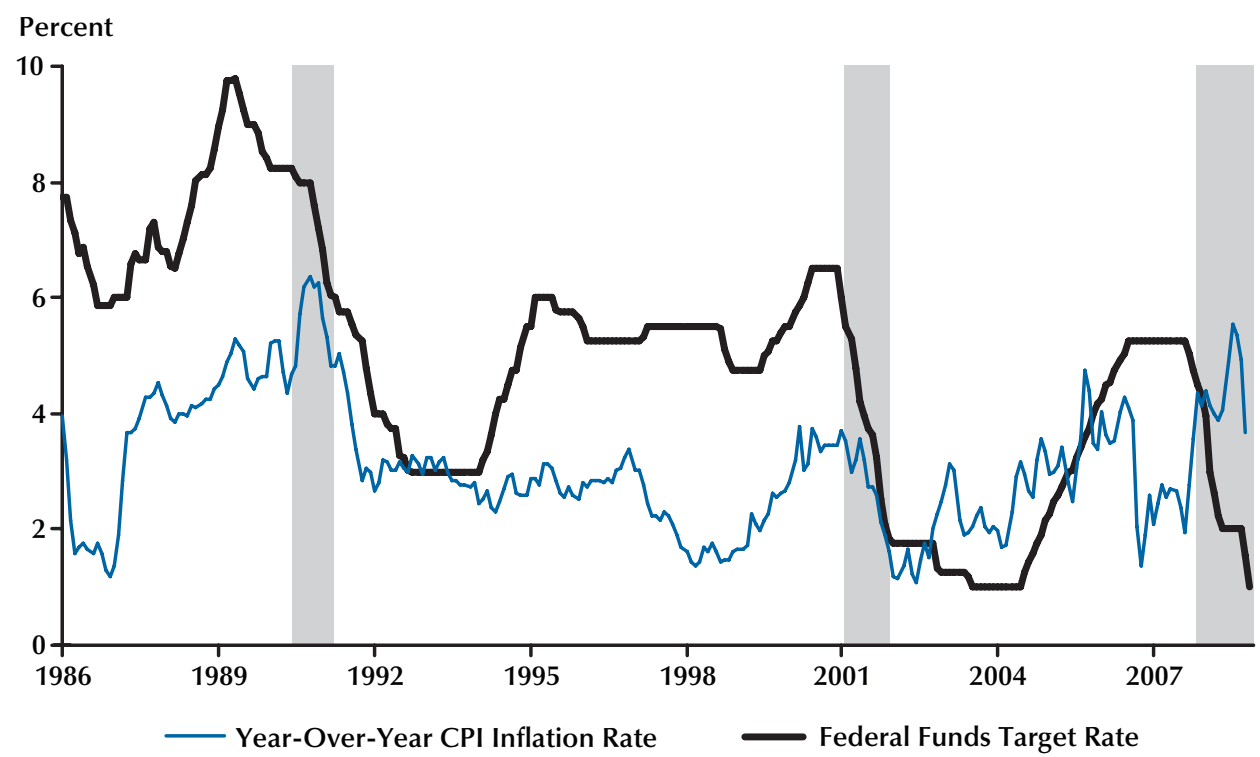

SOURCE: Federal Reserve Board, Bureau of Labor Statistics, National Bureau of Economic Research.

\section{B. Japan Policy Rate and Year-Over-Year Inflation Rate, January 1986-October 2008}

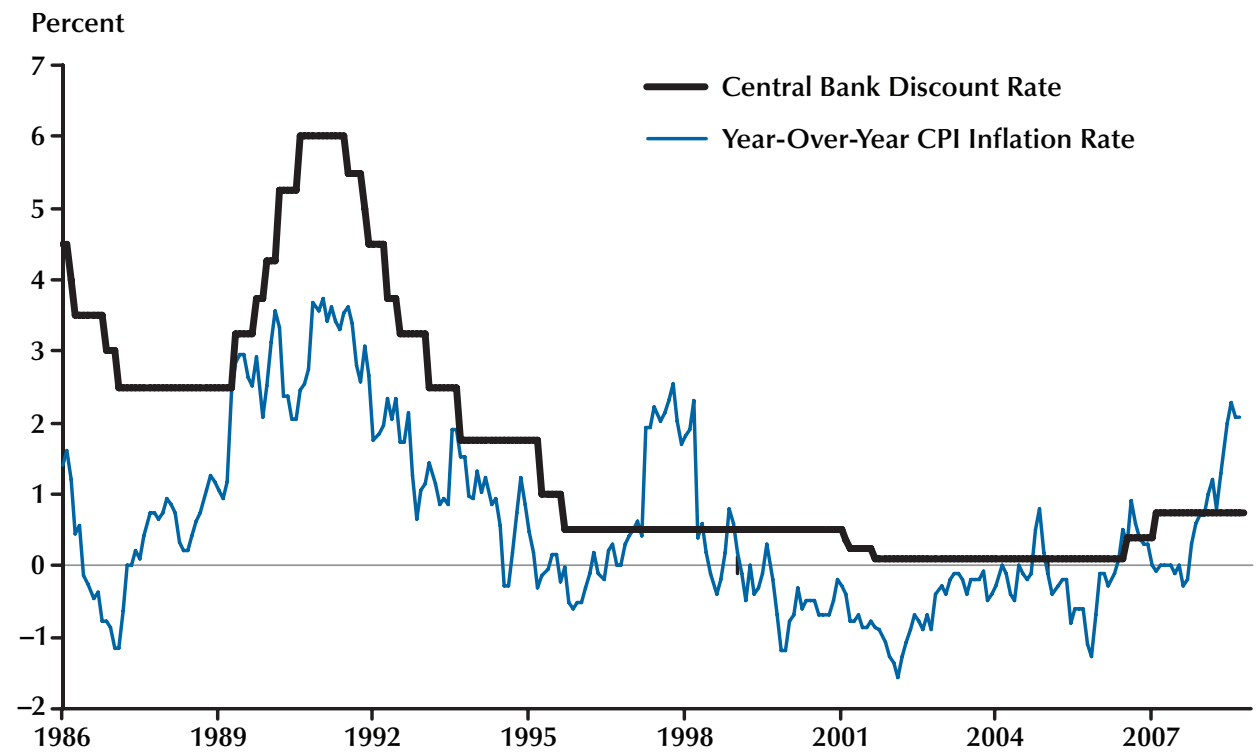

SOURCE: Organisation for Economic Co-operation and Development. 
At least since the 1980s, fiscal policy defined by deficit spending has had a negative connotation in many macroeconomic policy circles. Former Council of Economic Advisers Chairman N. Greg Mankiw, writing in 1991, listed as his "dubious Keynesian proposition \#4" the idea that "fiscal policy is a powerful tool for economic stabilization." He included this sentence: "In the United States today, fiscal policymakers have completely abdicated responsibility for economic stabilization." That was 1991, but I think it is a fair assessment of the thinking in much of the economics profession up until the current financial market turmoil. Fiscal policy, at least in the United States, was viewed as important for the macroeconomy, but from a longer-run perspective. To the extent there are stabilization goals-goals requiring time-critical policy interventions-the usual idea is that certain types of tax cuts might be beneficial, but that otherwise the effort is best left to monetary policy. Not least in this thinking is that the Fed can act relatively quickly, while the political process tends to be much slower and more cumbersome.

Yet, during the fall of 2008 in particular, fiscal policy conceived of as more direct intervention in the operation of private sector firms has emerged as a leading tool to combat ongoing financial market turmoil. This is so, not just in the United States, but globally. ${ }^{3}$ The passage of the Emergency Economic Stabilization Act (EESA), with authorization for the Treasury to spend up to $\$ 700$ billion to help return financial markets to more normal operation, has put the focus going forward squarely on fiscal responses. This created in a matter of weeks a very different policy environment from the one that had existed in the United States for the past 25 years.

The original idea behind the EESA was to create a market for the illiquid asset-backed securities and related instruments that are at the heart of the present situation. These assets have current prices, to the extent that they can be determined, that are very low, the so-called fire sale price, because so many firms would like to sell their holdings and few buyers exist in the current cli-

3 International Monetary Fund (2008, "Recent Central Bank and Government Actions," pp. 7-10). mate. However, these securities also have a higher, hold-to-maturity price that reflects the likely value of the stream of revenue for a patient investor who is willing to simply hold the asset for a period of time. Under the original EESA proposal, the government would play the role of the patient investor, buying the securities at a reverse auction and holding them or selling them at a future moment when financial market stress has receded. In principle, this idea could be executed at no ultimate cost to the taxpayer, although taxpayer money would be put at risk. ${ }^{4}$ An important part of the concept is that taxpayer money would be used to purchase assets that would then be sold in the future, recouping most or all of the initial outlay. The government would not have to purchase all assets, only enough to credibly create a market. I thought such a program, if it could be executed on a sufficient scale, may have helped to liquefy illiquid asset-backed securities markets and so may have helped progress toward an orderly financial market consolidation. This, in turn, would have helped to reduce or eliminate the downside risk to economic performance.

As events have transpired, the asset-purchase program has been put on hold. Given the rapid flow of events, capital purchases came to be viewed during the autumn as a simpler, more timely, and more direct method of intervention. The Treasury's capital injection program has taken the bulk of the resources from the first $\$ 350$ billion tranche of the $\$ 700$ billion appropriation.

\section{CONCLUSIONS}

I have described three funerals and a wedding. The ongoing financial market turmoil may have caused the death of many cherished ideas about

\footnotetext{
4 One place to look for a model for handling financial crises of this magnitude is the Nordic countries during the early 1990s. For a recent summary, see the speech by my friend and colleague Seppo Honkapohja, a governor at the Bank of Finland (Honkapohja, 2008). These countries were hit by severe financial turmoil and sharp recessions, in part associated with currency crises, in the early 1990s. The general response was for the governments to take equity positions in banks and to manage the resulting consolidation in the industry. As Honkapohja documents, the ultimate expense to the taxpayers in these countries was less than the initial outlay of government funds.
} 
how the macroeconomy operates. One funeral was for the idea of the Great Moderation. Certainly financial markets have seen exceptional volatility recently, and some behavior in those markets has been unprecedented. Still, I am not ready to bury the Great Moderation yet-we will need a lot more very volatile data on the real side of the economy to truly depart from the experience of the past 25 years. A second funeral was for our financial system as we have known it. That transformation has occurred and continues, with repercussions for U.S. and global financial market regulation. A third funeral was for monetary policy defined as nominal interest rate targeting. At least over the near term, any additional influence through interest rate reductions will be limited, and the focus of monetary policy may turn to quantity measures. The wedding - the idea on the rise-is fiscal policy defined as more direct intervention in certain parts of the private sector. While the Fed will continue to be innovative in providing liquidity to markets through existing facilities and possibly some new programs, an important part of the response to ongoing financial market turmoil will come from fiscal policy intervention. This runs counter to much of the thinking in macroeconomic policy circles over the past two decades. It may be discomforting or rewarding or both, but stabilization policy in the coming months and quarters is likely to look very different from what we have been accustomed to seeing.

\section{REFERENCES}

Bullard, James B. and Singh, Aarti. "Learning and the Great Moderation.” Working Paper 2007-027a, Federal Reserve Bank of St. Louis, June 2007; research.stlouisfed.org/wp/2007/2007-027.pdf.

Hoenig, Thomas M. "Global Financial Crisis and the Regulatory Environment: Where Do We Go From Here?" Presented at the Institute of International Bankers, New York, November 17, 2008; www.kansascityfed.org/SpeechBio/HoenigPDF/ Hoenig.Global.11.17.08.pdf.
Honkapohja, Seppo. "The 1990's Financial Crises in Nordic Countries." Presented at the Global Interdependence Center, Philadelphia, September 28, 2008; www.bof.fi/NR/rdonlyres/055DF411-915C4A0F-8B1C-B756928E319F/0/ 080928_SH_Nordic_ model.pdf or www.interdependence.org/docs/ The_1990_Nordic_Crisis_Seppo_Honkapohja.pdf.

International Monetary Fund. "Global Financial Stability Report: Financial Stress and DeleveragingMacrofinancial Implications and Policy," Washington, DC: IMF, 2008; www.imf.org/external/ pubs/ft/gfsr/2008/02/pdf/text.pdf.

Mankiw, N. Gregory. "The Reincarnation of Keynesian Economics.” NBER Working Paper No. W3885, National Bureau of Economic Research, October 1991 (issued July 1992); www.nber.org/papers/ w3885.pdf.

Paulson, Henry M. Jr. "Fighting the Financial Crisis, One Challenge at a Time." New York Times, November 17, 2008; www.nytimes.com/2008/11/18/ opinion/18paulson.html.

Plosser, Charles I. "Some Thoughts on the Economy and Financial Regulatory Reform." Presented at The Economics Club of Pittsburgh, November 13, 2008; www.philadelphiafed.org/publications/speeches/ plosser/2008/11-13-08_economics-club-ofpittsburgh.pdf.

Stock, James H. and Watson, Mark W. "Has the Business Cycle Changed and Why?" in Mark Gertler and Kenneth S. Rogoff, eds., NBER Macroeconomics Annual 2002. Volume 17. Cambridge, MA: MIT Press, 2003, pp. 159-218. 